\title{
INFANTILE HYSTERIA AND INFANTILE SEXUALITY IN LATE NINETEENTH-CENTURY GERMAN-LANGUAGE MEDICAL LITERATURE
}

by

\section{K. CODELL CARTER*}

BECAUSE one focus of Freud's work was his theory of infantile sexuality, there has been some interest in identifying other nineteenth-century writers who discussed this phenomenon. ${ }^{1}$ Also, because of Freud's early papers on male hysteria, there has been interest in nineteenth-century beliefs about the occurrence of hysteria in males. ${ }^{2}$ Curiously enough, however, almost no one seems to have paid much attention to the significant body of nineteenth-century medical literature on infantile hysteria. ${ }^{3}$ Yet, in German-language medical literature of the second half of the century, infantile hysteria regularly received more attention than male hysteria and it was usually associated with infantile sexuality. Moreover, some earlier sources that Freud acknowledged in his work on infantile sexuality are from this literature. ${ }^{4}$ The discus-

*K. Codell Carter, PhD, Chairman, Department of Philosophy, Brigham Young University, Provo, Utah 84601, USA.

\footnotetext{
${ }^{1}$ See, for example, Henri F. Ellenberger, The discovery of the unconscious, New York, Basic Books, 1970; Stephen Kern, 'Freud and the discovery of child sexuality', Hist. Child. Quart., 1973, 1: 117-141; and Frank J. Sulloway, Freud, biologist of the mind, New York, Basic Books, 1979.

${ }^{2}$ See, for example, Ilza Veith, Hysteria: the history of a disease, Chicago, University of Chicago Press, 1965; Kenneth Levin, 'Freud's paper "On male hysteria" and the conflict between anatomical and physiological models', Bull. Hist. Med., 1974, 48: 377-397; Hanna Decker, Freud in Germany, New York, International Universities Press, 1977; and K. Codell Carter, 'Germ theory, hysteria, and Freud's early work in psychopathology', Med. Hist., 1980, 24: 259-274.

${ }^{3}$ There is no mention of infantile hysteria by Ellenberger, Decker, Veith, nor Ernest Jones (The life and work of Sigmund Freud, New York, Basic Books, 1953). Kern discusses several individuals who gave attention to infantile hysteria, for example, Wilhelm Stekel, Eduard Henoch, and S. Lindner, but he himself never mentions it. Sulloway mentions infantile hysteria three times. First, in discussing a passage in which Freud presupposed that children are incapable of sexuality and so concluded that sexuality cannot always be the cause of hysteria (Freud's reasoning at this point is discussed below). Second, in a discussion based on a mistranslation of a remark by Heinrich von Bamberger (Wien. med. Presse, 1886, 27: col. 1409). Bamberger was discussing a woman who had had hysteria for two years - Sulloway takes him to be talking about a two-year-old girl hysteric. Third, Sulloway mentions Freud's later view that even in childhood various neuroses, such as hysteria, can be sexual in origin. None of these writers seems to have been aware of the significance of infantile hysteria in late nineteenth-century medical literature. Elisabeth Kloë and Hildburg Kindt have written on the history of infantile hysteria. 'Zur Enstehung und Entwicklung des kindlichen Hysteriebegriffes', Gesnerus, 1981, 38: 281-300. This publication, which I learned of only in the proof stage of the present essay, contains a reference to an earlier monograph by Kloë; Hysterie im Kindesalter, Freiburg, E. Seidler, G. Keil and B. Kuhlo, 1979. Unfortunately, time constraints have made it impossible for me to examine this monograph.

'For example, in 'The aetiology of hysteria' Freud acknowledged Wilhelm Stekel's work, and in 'Infantile sexuality' he mentioned S. Lindner. See Sigmund Freud, The standard edition of the complete psychological works of Sigmund Freud, James Strachey (editor), London, Hogarth Press, 1962, vol. 3, p. 207 and vol. 7, p. 179 respectively.
} 


\section{Infantile sexuality and infantile hysteria}

sion of infantile hysteria is, therefore, an important element in the background against which Freud worked.

Beginning about the middle of the century, paediatricians began reporting cases of hysteria among children and infants. ${ }^{5}$ For example, in the two defunct paediatric periodicals, Journal für Kinderkrankheiten (published from 1843 to 1872) and Jahrbuch für Kinderheilkunde (published from 1858 to 1939), one finds the first report of infantile hysteria in $1853,{ }^{6}$ and there are then subsequent reports in 1876,1878 , and each year thereafter until the end of the century. ${ }^{7}$ Infantile hysteria did not receive attention in general medical literature until somewhat later. If one examines the Wiener medizinische Wochenschrift, the Wiener medizinische Presse, and the Berliner klinische Wochenschrift, as typical examples, one finds the first mention of infantile hysteria (a ten-year-old boy) in 1868. The first discussion of the phenomenon was in 1880 and there were then articles or reports in $1881,1883,1884,1885,1886$, 1888 , and $1892 . .^{8}$ Between 1880 and 1896 , just under one-third of all major articles on hysteria in German-language medical periodicals were specifically on infantile or childhood hysteria, and cases are cited in most of the other articles on the disease. Thus, while infantile hysteria was scarcely mentioned at all in general medical literature prior to about 1880 , in the last two decades of the century it was frequently discussed and, what may be more indicative of interest, major articles on infantile hysteria were frequently reviewed in periodicals other than those in which they were published.9 One finds roughly the same situation in the Lancet. Apart from one isolated report of a hysterical ten-year-old girl in 1862, the first reports of hysteria in children were in 1883 - there were two cases, an eight-year-old girl and a ten-year-old boy. ${ }^{10}$ Through the next decade there were regular reports of hysterical children: in 1885 , an eleven-year-old boy; in 1888, cases of eight- and eleven-year-old boys; in 1890 , a twelve-year-old and two more eleven-year-old boys; in 1891, cases of children aged six, ten, and twelve; in 1892 another six-year-old; and in 1893, there was an extensive essay on hysteria in which the author discussed nineteen cases of hysterical children, ten male and nine female. ${ }^{11}$

Throughout the nineteenth century, physicians seem not to have recognized either

${ }^{5}$ For some early references see Hermann Smidt, 'Ueber das Vorkommen der Hysterie bei Kindern', $J b$. Kinderheilk., 1880, 15: 1-22, pp. 1-9.

' $J$. Kinderkrankh., 1853, 21: 271 . The author of this early essay used the adjective "hysterical" but did not actually say that the child in question was a hysteric.

' For early reports see $J b$. Kinderheilk., 1876, 10: 400, 422; 1878, 12: 158; 1879, 13: 96; 1880, 14: 1, 297; 1881, 16: 288; 1882, 18: 309; 1883, 19: 247; 1884, 21: 438, 505; 1885, 22: 153, 242, 353.

8 Wien. med. Wschr., 1868, 18: 107; 1880, 38: 956; 1883, 41: 385; 1885, 42: 1305-1308, 1338-1342, 1368-1371, 1401-1405; 1888, 46: 431-433; 1892, 50: 1893; Wien. med. Presse, 1881, 22: 916-918, 951f, 980-982, 1006-1009; Berl. klin. Wschr., 1884, 21: 330f; 1886, 23: 511-515, 534-537; 1892, 29: 841-845.

9 By contrast, male hysteria is mentioned at a much more constant rate in journal articles throughout the century. For some references, see Carter, op. cit., note 2 above, p. 265. Kloë and Kindt also note that children were first diagnosed as hysteric at about the middle of the nineteenth century. Op. cit., note 3 above, p. 286.

${ }^{10}$ Lancet, 1862 , ii: $52 ; 1883$, i: 547 , ii: 106 , respectively.

"Ibid., 1885, ii: 126; 1890, i: 924 , ii: 1322; 1891, i: 312, ii: 809; 1892, ii: 1444; 1893, i: 1185 , respectively. 


\section{K. Codell Carter}

the possibility or the desirability of identifying single necessary causes for all cases of specific diseases. In this respect, discussions of hysteria were entirely typical - one finds only long lists of unrelated causes no one of which could have been operative in more than a few of the cases. ${ }^{12}$ But while different causal factors were identified, everyone seems to have recognized various sexual phenomena as particularly significant. Of course, longstanding recognition of male hysteria had thoroughly exploded the old notion that hysteria was associated with movements of the uterus. ${ }^{13}$ By the middle of the nineteenth century, physicians were giving attention to other kinds of sexual causes. For example, physicians frequently identified inadequate normal sexual release and the resulting disappointment and frustration, as well as masturbation and other specific sexual practices, as particularly common causes of hysteria. Various factors pointed in this direction. First, the disease was observed most frequently in unmarried women and men between puberty and (in the case of women) menopause. Moreover, whereas prostitutes and members of the lower economic classes (who were generally believed to be less virtuous) were known to have a low incidence of hysteria, ${ }^{14}$ it was widely believed that sexually deprived populations were particularly subject to the disease. ${ }^{15}$ Second, the behaviour of patients during attacks could often be interpreted as suggesting a state of sexual deprivation. For example, near the beginning of the century, John Elliotson discussed a case in which "the patient called out in her fits for James, and some wags thought this was a spontaneous call of nature, indicating what remedy was required, and that I ought to have prescribed James' powder." 16 Third, there was a substantial body of anecdotal evidence associating hysteria with sexual deprivation. In his autobiographical writings, Freud provided three examples of such evidence. ${ }^{17}$ By the last decades of the century, there was a

12 Typical discussions mention heredity, physiological abnormalities, bodily disturbances, shocks to the circulation or nervous systems, social factors such as unsuitable systems of education, miscellaneous concerns or cares, physical injuries such as blows to the head, infections, fevers, worms, exposure to the smoke of cigars, various diseases such as tuberculosis, syphilis, or typhoid fever, intoxication by various substances, use of alcohol, as well as the sexual phenomena discussed below. These and other causes are mentioned, for example, in Martin Cohn, 'Ueber die Psychosen im kindlichen Alter', Arch. Kinderheilk., $1883,4: 28-43$.

13 "Associating hysteria with the uterus is like associating melancholia with black bile." F. Tuczek, 'Zur Lehre von der Hysterie der Kinder', Berl. klin. Wschr., 1886, 31: 511-515, 534-537, p. 511.

${ }^{14}$ A study of prostitutes in Paris revealed that they have a very low incidence of hysteria. Lancet, 1836, ii: 159f. Various writers, including Freud, commented on the low incidence of hysteria among the lower classes. For example, Freud, 'The aetiology of hysteria', op. cit., note 4 above, pp. 207, 211.

is "A further important aetiological moment for the pathology of hysteria is abnormalities in sex life. The struggle against sexual excitement by nuns, frequent excitement without satisfaction in the wives of men who are libidinous but impotent, a relatively excessive excitability of women, and over-excitement through natural coitus or the unnatural satisfaction of sex drives most frequently cause hysterical neuroses." Moriz Benedikt, 'Hysteria', Wien. med. Wschr., 1868, 18: 68-70, 81-83, 105-108, 121-124, col. 107. In his early writings Freud occasionally mentioned nuns and well-behaved boys as particularly vulnerable to hysteria. See Freud, op. cit., note 4 above, vol. 1, p. 126fn, for some references.

${ }^{16}$ Lancet, 1830, ii: 234. Later in the century, the editors of the Lancet warned against being misled by the claims of hysterical women who were disposed to "develop one of the prurient states of mind ... and become the victim of a characteristic delusion of which the medical man in attendance [or, one might add, some male figure in the patient's immediate family circle] is readily made the primary figure". The editors pointed out that since practitioners are almost daily in positions of extreme delicacy in this regard, examinations of such women should always be conducted in the presence of reliable female witnesses. Lancet, 1883, i: 66, cp. 1877, i: 26. 


\section{Infantile sexuality and infantile hysteria}

widespread conception that hysteria was generally due to certain kinds of sexual experiences, especially to abuse or deprivation after arousal.

When, in this context, physicians discovered that adult hysteria could often (perhaps always) be traced to experiences in childhood, ${ }^{18}$ and that children and infants could themselves become hysterical, two conclusions were possible: one could infer either that sexual experiences of the relevant kind were possible in childhood or even in infancy, or that widespread beliefs about the sexual aetiology of hysteria were exaggerations. At this point some physicians faltered and took the second alternative - indeed, in an early publication, Freud himself used the fact of infantile hysteria as evidence that sexual experiences could not be as preponderant in the aetiology of hysteria as was generally believed. ${ }^{19}$ In fact, some physicians seem to have employed a concept of sexuality that precluded, by definition, the possibility that children and infants could engage in sexual activities. ${ }^{20}$ But this was by no means the most common reaction - as we will see, most physicians who wrote on hysteria seem to have preferred the first alternative.

As physicians became interested in infantile hysteria, they also began discussing a range of infantile activities that included, but was not limited to masturbation, and that bore obvious similarities to adult sexual behaviour. Consequently, there is a remarkable parallel between reports of infantile hysteria and reports of direct observations of these infantile forms of behaviour. This parallel is clearly illustrated in reports of the two phenomena that were published in the Journal für Kinderkrankheiten and the Jahrbuch für Kinderheilkunde. As mentioned above, cases of infantile hysteria were reported in one or other of the journals in 1855,1876 , 1878 , and each year thereafter. Cases of masturbation or other related forms of behaviour were reported in one or other of the journals in $1852,1860,1876,1879$, $1881,1885,1888$, and regularly thereafter. ${ }^{21}$ Neither infantile hysteria nor infantile sexuality was discussed or even regularly reported prior to about 1850; both

\footnotetext{
${ }^{17}$ In the early years of his work on hysteria, it was suggested to Freud - on three different occasions by three different persons - that hysteria was always sexual in origin. Freud recalled in later years that Breuer, Charcot, and Charobak had all suggested this to him, "but at the time I heard them I did not understand what these authorities meant; indeed they told me more than they knew themselves or were prepared to defend. What I heard from them lay dormant and passive within me, until the chance of my cathartic experiments brought it out as an apparently original discovery." Freud, 'On the history of the psychoanalytic movement', op. cit., note 4 above, vol. 14, pp. 13-15.

1 Several physicians suggested that this might be the case, for example, Smidt, op. cit., note 5 above, p. 5; L. Scherpf, 'Zur Aetiologie und Sympomatologie kindlicher Seelenstörungen', Jb. Kinderheilk., 1881, 16: 288; Schäfer, 'Ueber Hysterie bei Kindern', Arch. Kinderheilk., 1884, 5: 402, and P. J. Möbius, 'Ueber die gegenwärtige Affassung der Hysterie', Mschr. Geburtsh. Gynäk., 1895, 1: 12-21, pp. 17, 20.

19 Freud, 'Hysteria', op. cit., note 4 above, vol. 1, pp. 50f. This is from the article that Freud apparently wrote for Villaret's medical encyclopaedia.

${ }^{20}$ One physician observed "that the nervous excitement [that brings on hysteria] need not be sexual in nature follows from the fact that Fleischmann saw nursing infants and Jacobi saw three year old children masturbate to the point of orgasm". Smidt, op. cit., note 5 above, p. 17.

${ }^{21}$ Between 1843 and 1873 , the $J$. Kinderkrankh. contained only two discussions of juvenile masturbation, one in 1852 (19: 297-305) and one in 1860 (35: 321-329). At least the first of these clearly treated the practice as an anomaly. In the $J b$. Kinderheilk., there were reports or discussions in 1876, 10: 400, 422; 1879, 13: 155; 1881, 16: 294; 1885, 23: 460; 1888, 26: 413; and 1890, 31: 159. Childhood masturbation was also frequently mentioned in discussions of hysteria and of other nervous disorders.
} 
phenomena were discussed frequently only beginning about 1875 . Of course, given the widespread belief that hysteria was sexual in nature, interest in each phenomenon reinforced interest in the other. It seems likely, however, that the investigation of hysteria - especially infantile hysteria - was one factor that focused medical attention directly on the sexual behaviour of infants. The infantile patterns of behaviour were usually identified as possible causes of (or less often as symptoms of) hysteria and other nervous diseases. While physicians in the 1880 s seem still to have had some reservations about referring to these kinds of behaviour as sexual in the full sense, these reservations seem to have vanished by the end of the century. What one finds, therefore, is evidence of a gradual expansion of the concept of sexuality to include forms of behaviour that may not have been so classified even at the middle of the century. Moreover, while a few medical writers seem to have regarded infantile sexuality as an abnormality, ${ }^{22}$ there is also evidence that most physicians recognized it as almost universal.

We will now examine some of the specific essays that represent the movement I have outlined.

In 1860, Friedrich Jacob Behrend published an essay on stimulation of the sexual organs and masturbation among small children. ${ }^{23}$ In the essay he noted that physicians are frequently either asked for advice in dealing with childhood masturba-

${ }^{22}$ For example, in one paper, Richard von Krafft-Ebing considered abnormally early development of sexuality - which, he explained, meant development before puberty. He gave an example of an eight-yearold girl who had masturbated from the age of four, and who had engaged in intercourse with boys who were ten to twelve years old. Krafft-Ebing reported that she contemplated murdering her parents so that she could amuse herself with men. 'Ueber gewisse Anomalien des Geschlechtstriebs und die klinisch-forensische Verwertung derselben als eines wahrscheinlich functionellen Degenerationszeichen des centralen NervenSystems', Arch. Psychiat. Nerv. Krankh., 1877, 7: 291-312, pp. 299f. Various other writers regarded precocious sexuality as a significant symptom of emotional instability, Wilhelm Griesinger, 'Vortrag zur Eröffnung der psychiatrischen Clinic zu Berlin', Arch. Psychiat. Nerv. Krankh., 1868, 1: 638-657, p. 651.

Kloë and Kindt (op. cit., note 3 above) argue that discovery of the phenomenon of infantile hysteria provided a theoretically neutral lever that helped dislodge the concept of hysteria from the somatic (and particularly neurogenital) context in which it had developed from antiquity and, thereby, opened the way for a conception of the disease that was predominantly psychological in the modern sense. I find it implausible that applying an existing concept to a new class of cases would somehow divest the concept of the theoretical connotations with which it had previously become encumbered. On the contrary, it seems much more likely that those connotations would be imported, with the concept, into the new context of application. And, indeed, this seems to be precisely what happened. By the middle of the nineteenth century, hysteria was no longer directly ascribed to neurogenital abnormalities, but it still retained strong sexual associations. Recognition of infantile hysteria, therefore, fostered interest in infantile sexuality. This conclusion is not directly incompatible with the Kloë-Kindt conclusion; one can move away from a neurogenital conception of hysteria and still continue to regard the disease as a phenomenon that is generally sexual in nature. But if, as I am arguing, recognition of infantile hysteria went hand-in-hand with recognition of infantile sexuality, then, I think, the assumption on which Kloë and Kindt depend (namely, that diagnosing children as hysterics somehow provided physicians with a theoretically neutral class of cases that could be contemplated without distorting presuppositions) is not only implausible but false. Incidentally, Kloë and Kindt never mention the intimate association between recognition of infantile hysteria and recognition of infantile sexuality.

${ }^{23}$ Freidrich Jacob Behrend, 'Ueber die Reizung der Geschlechtstheile, besonders über Onanie bei ganz kleinen Kindern, und die dagegen anzuwendenden mittel', J. Kinderkrankh., 1860, 35: 321-329. In this period, "onanism" was often used as a synonym for "masturbation". 


\section{Infantile sexuality and infantile hysteria}

tion or are confronted by childhood illnesses caused by masturbation. He discussed a case involving regular masturbation from the third year of life. He cited numerous French, English, and German sources in which similar cases, some involving children as young as ten months, were reported. He noted that infants are sometimes observed to masturbate "while still at the breast". In some of his cases, masturbation was induced in consequence of contact with older children (usually because the child had slept with older children of the opposite sex), but he also referred to other cases in which the behaviour was apparently instinctive. He noted that by the time children reach eight or nine, masturbation is no longer uncommon.

In 1876, Abraham Jacobi published an extensive list of cases involving childhood masturbation; some were cited from other sources but many were from Jacobi's own practice. ${ }^{24}$ Jacobi felt that such activities often led to psychological disorders such as hysteria. He also cited various older statistical studies indicating that children constituted between ten and twenty per cent of all hysterics. Jacobi's essay received considerable attention - it was reviewed in various paediatric journals and was frequently cited in subsequent discussions.

Two years later, in 1878, Ludwig Fleischmann of Vienna published what may have been the first case reports of infantile masturbation in German-language general medical periodicals. ${ }^{25}$ Fleischmann referred to Jacobi as well as to many of the earlier authors mentioned in Behrend's survey, and he pointed out that infants had been observed to masturbate even before weaning. Fleischmann reported two such cases from his own practice - one involved a thirteen-month-old boy who had masturbated regularly since his fifth month, the other was a nine-month-old girl who had masturbated regularly for two months. In both cases the practice seemed to have been initiated by adult intervention. Fleischmann suggested, in fact, that nursing infants are usually, perhaps always, caused to masturbate because of the intervention of nurses or other adults. Fleischmann recognized that his patients were capable of, and regularly achieved orgasm. He noted that various authors recommended circumcision or, in the case of girls, scarification or even amputation of the clitoris. Fleischmann felt, however, that such drastic measures could only be justified in recalcitrant cases and would not generally be required in the treatment of infants.

In $1879, \mathrm{~S}$. Lindner of Budapest published a fascinating essay dealing with a range of oral practices that he referred to with the verbs ludeln and wonnesaugen, words for which there are no English equivalents. ${ }^{26}$ Ludeln includes habitual sucking of thumbs,

\footnotetext{
${ }^{24}$ Abraham Jacobi, 'On masturbation and hysteria in young children', Am. J. Obstet, Dis. Wom., 1875, 8: 595-606, and 1876, 9:218-238.

${ }^{25}$ Ludwig Fleischmann, 'Ueber Onanie und Masturbation bei Säuglingen', Wien. med. Presse, 1878, 19: $8-10,46-49$.

${ }^{26}$ S. Lindner, 'Das Saugen an den Fingern, Lippen etc. bei den Kindern (Ludeln)', Jb. Kinderheilk., 1879, 14: 68-91. Lindner pointed out that one's pipe is sometimes referred to as der Ludel, and that "ludeln and lull [same word in both German and English] are identical concepts." Freud's editor, James Strachey, points out in a footnote that "there seems to be no nursery word in English equivalent to the German "luschen" and "ludeln", used by Freud alongside of "wonnesaugen" ("sensual sucking") ["wonnesaugen" was also Lindner's word although neither Freud nor Strachey mention this]. Conrad in Struwwelpeter was a "Lutscher"; but, as will be seen from the context, "suck-a-thumbs" and "thumb-sucking" have, in fact, too narrow a connotation for the present purpose." Freud, op. cit., note 4 above, vol. 7 , p. 179fn. "Ludeln" appears not to have been a standard German expression even at the turn of the century; I do not find it in
} 


\section{K. Codell Carter}

fingers, teeth, or other parts of the body, or even specific foreign objects; it is often accompanied by (sometimes replaced by) other habitual practices such as twisting hair, rubbing the ear, throat, nipples, navel, or genitals. Partly because no clear causes could be identified, partly because the practice was sometimes closely associated with nursing, Lindner felt that every child had an innate disposition to ludeln, although, depending on circumstances, this disposition may not be realized in practice. Lindner reported cases of ludeln among infants as young as four months and several of his cases involved young persons who had passed puberty. Lindner noted that ludeln, like other habitual oral practices such as nursing, were sometimes accompanied by or led to masturbation; he also described in detail an ecstatic state that infants regularly achieved through ludeln. Lindner himself never referred to this ecstatic state as orgasm, and he never specifically identified ludeln as sexual, but the implications must have been clear to most of his readers. ${ }^{27}$

In 1880, Hermann Smidt published a discussion of infantile hysteria that began with a long survey of existing literature on the subject. ${ }^{23} \mathrm{He}$ identified Charles Lepois as the first person to have explicitly acknowledged hysteria among children (in 1618), but he noted that the occurrence of the disease among children whose sexual organs were not yet functioning could not really be understood until the disease was comprehended as a purely functional sexual disorder. He cited a wide range of different authors who discussed hysteria among children and infants. He then classified ludeln together with masturbation as possible causes of infantile hysteria. Interestingly enough, however, Smidt also said the following: "That the nervous excitement [that brings on hysteria] need not be sexual in nature follows from the fact that Fleischmann saw nursing infants and Jacobi saw three-year-old children masturbate to the point of orgasm." 29 Thus, Smidt did not regard infantile masturbation even to orgasm - as a manifestation of sexuality. ${ }^{30}$

In 1881, L. Scherpf cited Fleischmann and others to establish that masturbation may begin very early. ${ }^{31} \mathrm{He}$ observed that children of neuropathological stock may develop sexually at an early age. Such abnormally early development was said to lead instinctively to masturbation. Scherpf observed that normal children may also be led to masturbate through external influences. He also noted the frequent connexion between sexual abnormalities and religious fantasy.

In the same year, Eduard $\mathrm{H}$. Henoch observed "one hears on every side that

early twentieth-century dictionaries. However, Theodor Heinsium's four-volume Volkthumliches Wörterbuch, Hanover, 1820, has this to say under "ludeln": "so viel als saugen (in andern gemeinen Sprachorten lullen, lollen, lutschen); töne ohne worte singen, lullen."

${ }^{27}$ For example, Freud wrote that "Lindner himself clearly recognized the sexual nature of this activity and emphasized it without qualification." Freud, 'Infantile sexuality', op. cit., note 4 above, vol. 7, p. 180.

${ }^{23}$ Smidt, op. cit., note 5 above.

29 Ibid., p. 17.

${ }^{30}$ It is worth noting that while many of the earlier authors who discussed infantile masturbation spoke of "stimulation of the sexual organs," etc., they did not generally refer to these practices as sexual. It seems possible, therefore, that at this time, while there was no doubt about the fact of infantile masturbation, there was uncertainty about whether or not the practice could appropriately be called sexual.

${ }^{31}$ L. Scherpf, 'Zur Aetiologie und Symptomatologie kindlicher Seelenstörungen', Jb. Kinderheilk., 1881, 16: $267-301$. 


\section{Infantile sexuality and infantile hysteria}

onanism is the chief cause of the nervous disorders." ${ }^{32}$ However, Henoch disagreed; he felt that if this were the case, then the widespread practice of masturbation would have generated many more young hysterics than one actually encountered. Therefore, while admitting that masturbation was extremely common and an important cause of hysteria and that it must always be considered as a possible cause of hysteria even in the first year of life, he felt that its aetiological significance may have been exaggerated. Henoch's view, which appeared not only in his very popular text but also in the Wiener medizinische Wochenschrift, was widely known and frequently cited through the late nineteenth century. For example, Martin Cohn repeated Henoch's argument in an essay in 1883: "if an evil as enormously widespread as is onanism especially at puberty - had a seriously detrimental influence, extremely many persons would be psychologically disturbed." 33

In 1884, Schäfer published an extensive review of the literature on infantile hysteria. ${ }^{34}$ In the course of discussing the aetiology of the disorder, he noted the following: "If one concludes, certainly with good cause, that inadequate satisfaction of the sex drive, sexual abstinence, and still more sexual overstimulation in particular by onanism as the causal moment of hysteria among adults, so the practice of sexual abnormalities, particularly onanism, masturbation, plays a large role among children." 35 Nevertheless, following Henoch, he felt that masturbation was much more widespread than were the disorders to which it could lead. Schäfer's article was reviewed - almost paraphrased - by Maximilian Herz in the Wiener medizinische Wochenschrift. ${ }^{36}$ Herz felt that Schäfer had over-emphasized the aetiological significance of masturbation, but he too admitted that it often caused childhood hysteria. These authors all clearly regarded infantile masturbation as a manifestation of sexuality. That all four of these authors denied that masturbation was as important a cause of hysteria as was commonly believed on the grounds that the practice was much more widespread than the disease, shows both that masturbation was recognized to be extremely common and it also suggests that most physicians believed it to be a predominant cause of the nervous disorders. Of course, it would be impossible to recognize that masturbation is more common than the nervous disorders unless one were aware of persons who masturbated but remained healthy. Thus, this recognition, like the opinion that ludeln and masturbation, etc., were instinctive, suggested that most or all children were at least potentially sexually active before puberty.

Through the next decade, various authors identified infantile sexual stimulation as a possible cause of infantile hysteria, but, perhaps because of Henoch's obviously influential argument, it was usually mentioned only briefly and it was not discussed in detail as it had been by earlier physicians. ${ }^{37}$ Other writers continued to call attention

\footnotetext{
${ }^{32}$ Eduard H. Henoch, 'Die hysterischen Affektionen der Kinder', Wien. med. Presse, 1881, 22: 916-918, 951f, 980-982, 1006-1009, col. 1008.

${ }^{33}$ Cohn, op. cit., note 12 above, p. 41.

${ }^{34}$ Schäfer, op. cit., note 18 above.

35 Ibid., pp. 406f.

${ }^{36}$ Maximilian Herz, 'Ueber Hysterie bei Kindern', Wien. med. Wschr., 1885, 43: 1305-1308, 1338-1342, 1368-1371, 1401-1405.

${ }^{37}$ For example, Tuczek, op. cit., note 13 above; M. Duvoisin, 'Ueber infantile Hysterie', Jb. Kinderheilk., 1889, 29: 287-329; and F. Jolly, 'Ueber Hysterie bei Kindern', Berl. klin. Wschr., 1892, 29: 341-345. In
} 


\section{K. Codell Carter}

to the extensiveness of infantile sexual practices or to the early ages at which such practices could be observed. ${ }^{38}$

In 1895, Wilhelm Stekel published an essay entitled 'Ueber Coitus im Kindesalter' ${ }^{39}$ Stekel noted that physicians did not generally recognize that coitus - as opposed to simple masturbation or other sexual practices - was a common occurrence in childhood. After citing numerous physicians and anthropologists who had commented on the prevalence of masturbation among children, Stekel noted that childhood is the bridge by which Homo sapiens is connected to the animal world. He observed that children instinctively find the path to sexuality, but that such children also seem to know that this discovery must be hidden from their parents. He suggested that coitus or other experiences awaken sensitivity and are often the cause of early masturbation. Stekel noted that coitus seems to have no particular destructive influence on the health of the child. Indeed, his observations were based in part on strong and completely healthy men. Stekel then gave two case histories - one of a physician, the other of a jurist - who had frequently engaged in intercourse with playmates or relatives during childhood. Neither seemed to have any physical or psychological disturbances as a result of these experiences. He mentioned several other cases - usually involving children with whom he was working or about whom he had gathered information from colleagues.

By the time of Stekel's article, most physicians who wrote on these subjects seem to have acknowledged that instinctive sexual drives in children very commonly occasioned a wide range of practices including ludeln and auto and mutual stimulation of the genitals. These practices were consistently identified as sexual and were not believed to require the intervention of adults or older children.

\section{III}

By the end of the century, Freud had elaborated theories of hysteria and of infantile sexuality that employed many of the ideas found in the writings of his contemporaries. One such idea was that infants and children commonly experience sexual arousal and that under certain circumstances such experiences can result in serious psychological disturbances in later life. His own experiences with eighteen hysterics clearly pointed

\footnotetext{
'The aetiology of hysteria', Freud responded to the argument that Henoch, Cohn, Schäfer, and Herz had advanced to the effect that sexual activities cannot be the predominant cause of hysteria because such activities are much more common than hysteria. Freud wrote, "Now let us turn to the other objection, which is based precisely on an acknowledgement of the frequency of infantile sexual experiences and on the observed fact that many people who remember scenes of that kind have not become hysterics. ... It does not matter if many people experience infantile sexual scenes without becoming hysterics, provided only that all the people who become hysterics have experienced scenes of that kind. The area of occurrence of an aetiological factor may be freely allowed to be wider than that of its effect, but it must not be narrower. Not everyone who touches or comes near a smallpox patient develops smallpox; nevertheless infection from a smallpox patient is almost the only known aetiology of the disease." Freud, op. cit., note 4 above, vol. 3, p. 209. Freud was saying here that whereas this objection rests on the assumption that sexual activity is a sufficient cause of hysteria, in fact it should only be regarded as a necessary cause.

${ }^{38}$ For example, H. Hirschsprung, 'Erfahrungen über Onanie bei kleinen Kindern', Berl. klin. Wschr., 1886, 32: 628-631.

39 Wilhelm Stekel, 'Ueber Coitus im Kindesalter', Wien. med. Bl., 1895, 18: 247-249.
} 


\section{Infantile sexuality and infantile hysteria}

to this conclusion, ${ }^{40}$ but he was also undoubtedly aware of similar conclusions that had been announced by other physicians. In the medical literature of the time, infantile hysteria was almost universally associated with infantile sexuality - even those who felt that the aetiological significance of sexual abuse had been exaggerated admitted that the connexion could exist in particular cases and that such a connexion was universally recognized by physicians. In many respects, Freud's early work on infantile sexuality and on hysteria seems to be completely compatible with this literature. Kern has even surmised that "almost every element of Freud's theory of child sexuality was exactly anticipated, or in some way implied or suggested, before him."'41 This may be true, but a theory is more than the sum of its elements, and looking only at individual elements may obscure those very features of a theory that justify the claim of originality. I will conclude by considering one aspect of Freud's work in this area that is strikingly different from the writings of his predecessors.

Havelock Ellis and more recently Frank J. Sulloway have pointed out that in discussing infantile sexuality, Freud's language was characterized by a "revolutionary boldness". ${ }^{42}$ "Various medical authorities before Freud recognized the importance of sex as well as its aptitude to appear in childhood. But they had been careful to make their statements with moderation and to express them temperately, so that they might be accepted without arousing either enthusiasm or hostility."43 After quoting this passage from Ellis, Sulloway concludes, "Seen in these terms, it was not only what Freud said but how he said it that alienated many of his professional colleagues." 44 agree that Freud's language is strikingly different from that of his contemporaries, and that this difference may have alienated some of his colleagues. In view of the discussions summarized in the preceding section, however, the difference does not seem to be simply a matter of boldness. One final example from the literature on infantile sexuality will help to bring the difference into focus.

In 1898, Freud published Sexuality in the aetiology of the neuroses, the work that contains what have been identified as Freud's first pronouncements on the theory of infantile sexuality ${ }^{45}$ In the same year, J. K. Schmuckler published an entirely typical essay entitled 'Onanism in childhood' ${ }^{46} \mathrm{Sch}$ muckler discussed the widespread practice of masturbation both in schools and in homes; he concluded that until this depravity (Laster) is exterminated (ausgerottet) from homes it will continue to infect (inficieren) the schools. Among the causes of this depravity he identified such social innovations as the consumption of coffee and tea by children, dancing, riding bicycles, the practice of placing pockets in tight pants, lascivious paintings, statues, novels, and parties where one finds crowds of rosy-cheeked children, dressed in small frocks of fine material, with half-naked arms, feet, and breasts. Social and economic factors are also important: on the one hand, children raised in poverty experience crowded living

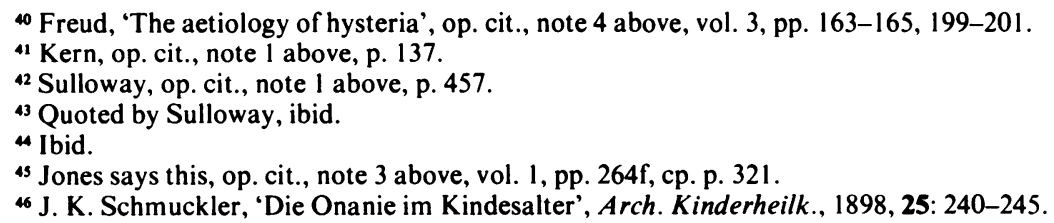


without proper supervision, while wealth produces indolence, inactivity, and effeminacy. It is the highest duty and responsibility of the paediatrician to concentrate on these possible sources of masturbation. The malignant (malignen) consequences of this evil (Uebel) include the usual range of neurological and psychological disturbances as well as general weakening of the system. Schmuckler discussed techniques for diagnosing and treating this depravity. He pointed out that it can only be controlled through a combination of medical, psychiatric, and pedagogical efforts and that all such efforts presuppose direct moral supervision by physicians and pedagogues. Since masturbation is a social phenomenon, the state and society at large have every right to oppose it vigorously. Parents, tutors, educators, and representatives of the medical profession must unite to fight this evil which threatens the very foundation of the well-being of society and of the state.

In comparison with his predecessors, Schmuckler's choice of terms is in no way unusual. Most of the physicians discussed in the preceding sections use precisely the same terms in their technical writings. For example, Scherpf, Henoch, Herz, Hirschsprung, and Stekel referred to infantile sexual practices as depravities (Laster); Henoch, Cohn, and Schäfer spoke of such practices as an evil (Uebel). In view of articles like Schmuckler's, it seems totally wrong to characterize pre-Freudian discussions of infantile sexuality as "temperate" or as "made with moderation". It is obvious that these discussions were - and were intended to be - much more inflammatory than Freud's. In contrast to these discussions, Freud's writings on infantile sexuality - which never contained such pejorative moralistic terms as "Laster" or "Uebel" - were dispassionate, disinterested, and strikingly secular and amoral. Insofar as Freud's medical contemporaries were shocked by his discussions of infantile sexuality, this aspect of his language, rather than his frankness, may have been what was at issue. 